れない。以上の諸観察から，ANによる肝ホモジェネー トの呼吸阻害として，遊離青酸以外の作用をむしろ重要 視しなければならない。またロダン法で検出される物質 が AN からの遊離青酸に目来するものかどうかについ ても, 疑問が残されている。これらの問題について, 現 在検討中である。

\section{0. アクロレインガスの人体に対する毒性について}

増田義德（鉄興社酒目工場）

アクロレインは，工業的には，人工香料アアリルアル コール，合成樹脂等の合成に用いられ，また，その强い 刺戟臭のために冷湅刜である塩化メチールの警戎臭をつ 汀るために用いられといら。この物質による中毒沈いい てはわが国には汪とんぞ見られない。

石䲓原料として積まれた油槽船の荷下ろし作業中に， 牛脂の分解産物であるグリセリンからアクロンインが発 生し，ガス中毒が抗こった。作業員並びにとの監督者は アクロレインガス中毒に関する知識肪全くなかったた め, 從来, 恕限度と考えられているガス濃度をはるかに こえた環境内で作業を実施し，ガス濃度と中毒症状との 関係を知る結果となった。そして，徒来の報告と，かな り異なる結果となったので報告する。

1. 作嶪を実施した船艙内のアクロレインガス濃度は 北川式検知管によると $10 \sim 30 \mathrm{ppm}$ で平均 $25 \mathrm{ppm}$ であ って，一般に考光られる恕限度 $0.5 \sim 1 \mathrm{ppm}$ をはるかに こ光, Hendersonらによる短時間内致死濃度 $10 \mathrm{ppm} の$ 2 倍以上の濃度を認めた。

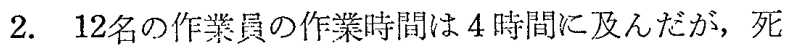
亡するものはなかったことはもらろん，症状としては， 呼吸器及び眼の刺戟症状が主体であって, 耐觉られない 程度ではあるが，作業は行なわれた。頭痛，食恣不振， めまい等を訴えるものも数名いた。

3. 船艙内のガスを慁いて，マウス４ 匹亿吸入させる と同時に，低酸溸濃度の負荷を与光，一方低酸素のみの 負荷を与えた 4 匹のマウスと死亡時間を比較したが，有 意差があり，アクロレインガスの毒性は明らかに証明で さた。

\section{1. 木曾地方にみられる上気道性疾患についての症 例報告}

小松䈏三男，伊藤公夫（信大衛生）

昨年の日本公兽衛生学会に和いて，長野県木算地方の 木工業従慈者の間にみられる，一つの新らしい職慈病と もいらべき上気道性疾患について報告した。今回は，こ
疾患つ病因等を考学る上で，一つつ乎がかかりともな るような顕著なる数例について，症例報告をする。

この疾患の概要をのべると，ネズコといら木材を加工

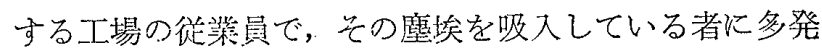
すること，そしてまた，この疾患にかかっている者の鼻 汁の中に，多数の恔酸球が登見されること，ネズコの浸 出液による皮内反応が，これらのネズコ取扱者に陽性に 出ることなどより，その成团は単なる塺埃の吸入による 機械的刺戟からは説明がつかず，アレルギー性のbので はないかと考えられるところのものである。

アレルギー性疾患の同定には，上記のよらな諸点の他 その抗原物筫と推定されるものによる誘発反応もまた欠 くことのできないものである。しかし喘息のょらにはげ しい発作の苦痛をともならものは, 誘発試験を行ならの は困難であり，それに現在，労働中の者では，はたして

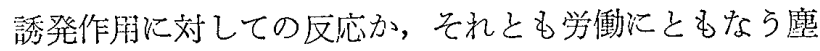
埃の吸入といら本茳の作朋に対しての反応であるかは区 別しにくい。しかし，この間の事情を偶然に説明してい ると思われる喘息の症例 4 例をくわしく報告する。その 活か，くしやみの発作発現についての症例報告及び同様 な作籍を長年継続しているにもかかわらず，全くこのよ らな症状を和こさない者について報告もあわ接て行ない たい。

\section{〔中毒一ベンゾール〕}

\section{2. ベンゼソ投与動物尿中のベンゼングライコール} とそのグルクロナイド，並びに芳察

佐藤德郎, 福山富太郎 (公衛院栄養) ベンゼングライコール（宗大中島・栗原氏より分与） は $2 \mathrm{~N}-\mathrm{NH}_{3}$ 飽和ブタノールで Rf $0.75,0.1 \mathrm{~N}-\mathrm{NH}_{3}$ 水 で 0.92 を示し，紫外線を吸収し， p-ニトロアニリン (1N-HCl 使用) のヂアゾ陽性, $\mathrm{NaIO}_{4}$-Schiff で黄色 のディホール反応陽性, 動物肝で, 括もにカテュール, 加水後フェノールの硫酸抱会物が兄られる。肝上清では 叔もにフェノールの抱合物をらるが，硫酸抱合をし脱水 により生ずるものと考えられる。

ベンゼン投与ウサギ疗に活性炭を加党, 活性孷を水, アンモニアで洗い, アンモニア性メタノール溶出， $45^{\circ}$ 以下で減珢濃縮 エーテルで振り，エーテル層をペーパ 一クロートにかけると， ベンゼングライコールと全く 同じ性質の物質がえられる。 $3 \mathrm{~g}$ のベンゼンから $1 \mathrm{mg}$ 以下の收量であった。エーテル抽出の残液に防ルク口 ニダーゼを働らかぬ，再びェーテル抽出すると，再び同じ 
物筫がえられる。尿中には不安定なグルクロナイドがあ り，稀酸でフェニルグルクロナイドを生じ，このものは 一方，グルクロニダーゼでベンドングライコールを生ず る。すなわらベンゼングライコールのグルクロナイドと 考它られる。

尿中にはメルカプツール酸の前駆物貿が存在するの が, ペーパークロマトで確認される。

ベンゼングライコールとメルカプッール酸前駆物質の 存在は, 両煋がエポキシドから生ずると考えると, ナフ タリン，ディヒドロナフタリンなどで得られた成績と一 致し，よく理解できる。ベンゼンは大部分がフェノール の方に代謝され，エポキシド，ベンゼングライコールか らフェノールとなるのは，中島らの実験から見ても少量 と考觉られる。ベンゼンからフェノール生成の酸化過程 酸の形成とともに未解決である。このエポキ シドは反応性に富み，組織のSH と反泪し，他の基飞附 加粦をつくりやすい。

223. ベンゼン中毒時における解畵酵素群活性の变化 について ( 3 )

池田正之（索大公衛）

村上 宏 (関西医大公衛)

生後㴔300日の去熱雄 Wistar 亲ラット（生後45日目 心去勢, 以後, 卵胞ホルモン 30 単位を週 2 回皮下注） 10 元を用い，エーテル麻酔下に，肝部分的摘出術を施し て, 肝内側在葉より切覑 1 1.5gをとり, その soluble fraction を, 酵素液として, 能勢 Lipmann 法によ り，p-nitro-phenyl-sulfate 合成酔素系活性を，また micro-sonal fraction を酥素液として, Dodgson et al 法により，arylsulfatase C 活性を，それぞれ定量 した。ついで約 6 週間の術惢回復期のあと，同一個体 を, benzol 濃度 $1000 \mathrm{ppm}$ に 7 8時間/日”5 日/週 曝 露して，白血球減少の度合いと上記酥素活性值との相関 について検討した。

Benzol 曝露第21日目の白血球減少の度合いと p-nitrophenyl 合成酵素系活性値との間には相関があり，酵 素活性值の高い個体では，白血球はあまり減少せだ，酵 素活性值の低い個体では，白血球減少の程度がより著る しい。（ $\mathrm{r}=0.68$; 危険率 $5 \%$ で有意)。Ary!-sulfatase $C$ 活性值と白血球減少とつ間にはとくに相関関係を認め ない。ラット肝硫酸抱合酵素活性が benzol に対する感 受性に和ける性差と成熟美の発現に関連を持りことを前 学会で報告したが，以上の成績から，同酵素活性は個体 差の発現にも深い関連を有すると考えられる。
224.

\section{について}

池曰正之（京大公衛）

Wistar 系ラットを用い，前学会での報告と同様の実 験計画に范って，成熟雄，成熟去勢雄（幼若時に去勢， 以後, 卵胞ホルモンを皮下注), 成熟䧳, 幼若雄, 幼若崊 の5群を用意し，各群の肝臓について，下記の䣼素を定 最した。

さらに，これら 5 群を benzol 濃度 $1000 \mathrm{ppm}$ に 7 〜 時間/日，5日/週曝露し，その白血球数の变化を追 求した。以上の穾駼から，グルクロン酸抱合酵素活性と benzol に対する感受性の差との関係，硫酸抱合酵素活 性とグルクロン酸抱合酵素活性との関係, $\beta$-glucuronidase, arylsulphatase 活性の関係について報告する。

定量酵素：(1) p-nitrophenyl glucuronide 合成酵 素; microsomal fraction を酵素液, UDPGA を補 酵菜とし Leloir et al 法の変法による。(2) p-nitrophenyl sulfate 合成酵素系; soluble fraction を酵 素液と乙能勢 Lipmann 法による。(3) B-glucuronidase； $700 \times \mathrm{g} \sim 10$ 分上清索酵素液， p-chlorophenyl glucuronide 基賢と乙, Spencer and Williams 法 による。(4) Arylsulfatase A+B； $700 \times \mathrm{g} \sim 10$ 分上清 を酵素液, 4-nitrocatechol sulfate 基質とし Roy 法 の Spencer and Williams 変法による。(5) Arylsulfatase $\mathrm{C}$; microsomal fraction 孝醉素液, p-acetylphenyl sulfate を基質とし Dodgson et al 法に よる。

225. ベンゼンおよびその同族体の中毒に関する研究 （b）ベンゼン中意 義について

野見山一生，広沢毅一，小松富三男(信大衛生)

Benzene 中毒発現の machanism には，いなだ不明 の点が多く, benzene 中毒が benzene そのものによる ものか, benzeneの代謝産物によるるのかも，わからな いといらのが現状である。そこで我々は，benzene 中請 に括ける benzene 代謝座物の役割を検討するために， 白鼠に 3-amino，1,2,4-triazol を腹腔内投与して， 肝の benzene 酸化能を低下させ, triazol 処理白鼠が 正常 benzene 酸化能を有する哭処理の白鼠にくらべて (同一量 benzene を投与された場合)，benzene 中毒の 症状を発見しやすいか否かを研究した。

実験動物は $150 \mathrm{~g}$ 前後, 生後 6 週令の Donryu 白鼠 